\title{
Cytoskeleton, cytoskeletal interactions, and vascular endothelial function
}

\author{
This article was published in the following Dove Press journal: \\ Cell Health and Cytoskeleton \\ 4 December 2012 \\ Number of times this article has been viewed
}

\author{
Jingli Wang' \\ Michael E Widlansky ${ }^{1,2}$ \\ 'Department of Medicine, \\ Cardiovascular Medicine Division, \\ ${ }^{2}$ Department of Pharmacology, \\ Medical College of Wisconsin, \\ Milwaukee, Wisconsin, USA
}

Correspondence: Michael E Widlansky Master of Public Health Program, Medical College of Wisconsin, 9200 W Wisconsin Avenue, FEC Suite E5I00, Milwaukee, WI 53226, USA

Tel + I $4 \mid 49556755$

Fax + I 4149556203

Emailmwidlans@mcw.edu

\begin{abstract}
Far from being inert, the vascular endothelium is a critical regulator of vascular function. While the endothelium participates in autocrine, paracrine, and endocrine signaling, it also transduces mechanical signals from the cell surface involving key cell structural elements. In this review, we discuss the structure of the vascular endothelium and its relationship to traditional cardiovascular risk factors and clinical cardiovascular events. Further, we review the emerging evidence that cell structural elements, including the glycocalyx, intercellular junctions, and cytoskeleton elements, help the endothelium to communicate with its environment to regulate vascular function, including vessel permeability and signal transduction via nitric oxide bioavailability. Further work is necessary to better delineate the regulatory relationships between known key regulators of vascular function and endothelial cell structural elements.

Keywords: endothelium, shear stress, eNOS, cardiovascular risk factors, glycocalyx
\end{abstract}

\section{Introduction to the vascular endothelial cell}

The monolayer of cells lining the innermost surface of the circulation system including the heart chambers and blood vessels was originally named the "endothelium" by Swiss anatomist Wilhelm His Sr in 1865., ${ }^{1,2}$ Since then, endothelial cells have been extensively studied. ${ }^{3-13}$ Early hypotheses that the endothelium was a static, passive mechanical barrier, present solely to separate the blood flow from the vessel wall and tissues, have given way to the modern concept of the endothelium as a key, biologically active, cell layer.

In the average adult, the endothelium has a net weight of $\sim 1 \mathrm{~kg}$ and lines a total surface area measuring 300 1000 $\mathrm{m}^{2} .{ }^{1,6,14}$ Endothelial cells are primarily mononuclear cells with slightly basophilic cytoplasm containing various intracellular organelles (eg, the Golgi complex, mitochondria, endoplasmic reticulum, and Weibel-Palade bodies). ${ }^{1,15,16}$ Endothelial cells can become multinucleated under both normal ${ }^{1}$ and atherosclerotic conditions, ${ }^{17,18}$ although the significance of this phenomenon is unclear. The average endothelial cell measures approximately $50 \times 11 \mu \mathrm{m}$ (length $\times$ width), ${ }^{1}$ with a thickness ranging from 0.1 to $1.0 \mu \mathrm{m} .{ }^{1,16,19}$ However, the height of endothelial cells vary relative to their exposure to shear and anatomical location. ${ }^{20}$

Endothelial cells are generally polygonal ${ }^{21}$ and appear similar to cobblestones. ${ }^{22,23}$ Their shape is determined by multiple factors, including the cell structural elements, cell metabolism, mechanical forces, and cell-cell and cell-matrix interactions. ${ }^{1,24}$ For example, the arterial endothelium lining tends to be thinner and more parallel to the direction of blood flow than the venous endothelium. Younger endothelial cells with 
faster growth rates are thicker than older cells. ${ }^{1}$ Shape also changes with vascular tone.

\section{Roles of the vascular endothelium Regulation of vasodilation and angiogenesis}

The non-diseased endothelium regulates pro-vasodilatory and vasoconstrictive influences, balancing autocrine, paracrine, and endocrine influences to maintain normal vascular physiology. Nobel Prize-winning work revealed that a central paracrine factor responsible for regulating vascular function is nitric oxide (NO). ${ }^{25-27} \mathrm{NO}$ is synthesized in the endothelium by nitric oxide synthase (eNOS) through the enzymatic conversion of L-arginine to L-citrulline. After diffusing into smooth muscle cells, NO generates cyclic guanosine monophosphate from guanosine triphosphate by activating soluble guanylyl cyclase. Further, NO induces vascular smooth muscle relaxation by decreasing cytosolic $\mathrm{Ca} 2+$ and dephosphorylating myosin light chains in smooth muscle cells. ${ }^{28-30} \mathrm{NO}$ can also directly activate the big conductance calcium-activated potassium channel (BKCa) channel on the membrane of smooth muscle cells to cause vasodilation. ${ }^{16}$ Other vasoactive factors produced by the endothelium include endothelial-derived hyperpolarizing factors such as hydrogen peroxide, cytochrome 450 metabolites, C-natriuretic peptide, prostacyclin, and endothelin-1. ${ }^{6,16,25,31}$ Endothelial cells also secrete various growth factors, including vascular endothelial growth factor, to participate in endothelial regeneration and angiogenesis. ${ }^{32,33}$

\section{Control of vascular inflammation processes}

The endothelium is essentially devoid of evidence of inflammation under homeostatic conditions. ${ }^{34}$ However, the endothelium plays a central role in integrating local and systemic inflammatory signals, leading to alterations in the endothelial phenotype characterized by increased local and systemic endothelial inflammation. ${ }^{35-37}$ Interestingly, NO bioavailability plays a central role in regulating the inflammatory response. Normal homeostatic levels of NO limit endothelial expression of adhesion molecules (vascular cell adhesion protein 1, intercellular adhesion molecule 1, and P-selectin) ${ }^{16,38}$ and the production of leukocyte/monocyte recruitment factors. ${ }^{39,40}$ This prevents the adherence of leukocytes and monocytes from the bloodstream onto the endothelial surface. ${ }^{41-43}$ Further, NO helps to maintain normal endothelial layer permeability by stabilizing physiological cytoskeleton distribution, inhibiting penetration of pro-inflammatory cells into subendothelial space. ${ }^{44}$ Reduced NO bioavailability may disrupt the cytoskeletondependent structural integrity of the endothelium by inhibiting Rho activity. ${ }^{45}$

\section{Regulation of thrombosis and fibrinolysis}

The normal vascular endothelium also carefully balances prothrombotic and pro-fibrinolytic factors. ${ }^{46}$ Endotheliumderived NO plays a central role in this balance by limiting platelet activation and adhesion. ${ }^{47} \mathrm{NO}$ inhibits platelet aggregation by inhibiting key platelet-platelet interactions. ${ }^{48,49}$ NO also inhibits the expression of plasminogen activator inhibitor-1, stimulating fibrinolytic pathways. ${ }^{50}$ Factors other than NO play complimentary roles in regulating thrombosis and fibrinolysis at the level of the endothelium. For example, thrombomodulin expressed on endothelial cells binds thrombin to block thrombin-triggered thrombus formation. Further, thrombomodulin reduces activated factor $\mathrm{V}$ through activation of proteins $\mathrm{C}$ and $\mathrm{S}$ to inhibit thrombin formation. ${ }^{51}$

\section{Endothelial dysfunction and cardiovascular risk}

Traditional (hypertension, dyslipidemia, aging, diabetes mellitus, smoking) and emerging (eg, inflammation, hyperhomocysteinemia) cardiovascular risk factors impair endothelial function in humans at least in part through reduced NO bioavailability. ${ }^{46}$ The inflamed, prothrombotic, pro-proliferative, and vasoconstrictive phenotype observed secondarily to reduce NO bioavailability is commonly referred to as "endothelial dysfunction."

Individual risk factors induce a dysfunctional endothelial phenotype through multiple mechanisms. While an exhaustive description of the effects of each cardiovascular risk factor on the vascular endothelium are beyond the scope of this review, a brief discussion of the effects of key traditional risk factors on endothelial function will give a sense of the common effects of otherwise disparate risk factors on the vascular endothelium. Hypertension induces vascular inflammation and excessive reactive oxygen species (ROS) production from multiple sources, including nicotinamide adenine dinucleotide phosphate (NADPH) oxidase and uncoupled eNOS. ${ }^{52,53}$ Elevated angiotensin II levels also contribute to hypertension, at least in part through increased NADPH oxidase activity. ${ }^{54-57}$ 
Endothelial function is impaired and blood pressure is increased in eNOS synthase knockout animals, ${ }^{58}$ further indicating that eNOS is a key factor in maintaining normal vascular function.

The insulin resistance also impairs endothelial function through reduced NO bioavailability and increased oxidative stress. ${ }^{59,60}$ Hyperglycemia exposure increases endothelin-1 secretion ${ }^{61}$ and impairs NO bioavailability, both through reduced eNOS activity and increased NO destruction. Further, hyperglycemia in insulin resistance also increases vascular oxidative stress through uncoupling eNOS, ${ }^{62-64}$ activating NADPH oxidase, ${ }^{65}$ inhibiting ROS scavenging systems, ${ }^{66}$ and stimulating mitochondrial ROS production. ${ }^{67-69}$

Hypercholesterolemia also impairs endothelial function. ${ }^{70-75}$ Oxidized low-density lipoproteins (oxLDL) disrupt NO production from eNOS function by reducing the bioavailability of tetrahydrobiopterin (BH4), a key co-factor for NO production from eNOS. Loss of BH4 bioavailability ${ }^{76-79}$ encourages superoxide production from eNOS rather than NO. Administration of BH4 to patients with hyperlipidemia blunts hypercholesterolemiaassociated endothelial dysfunction. ${ }^{80-82}$ oxLDL upregulates the production of the endogenous eNOS inhibitor, NG-NGdimethyl-L-arginine (asymmetric dimethylarginine) ) $^{83,84}$ and promotes the association of eNOS with caveolin- $1{ }^{85} \mathrm{In}$ addition, oxLDL elicits a vascular inflammatory response and increases endothelial permeability to inflammatory cells, inducing a vicious cycle leading to the formation of atherosclerotic plaques. ${ }^{86-88}$

In summary, the vascular endothelium integrates the effects of extrinsic influences on the vascular endothelium with intrinsic susceptibility to external influences on endothelial health, making measurements of endothelial function an excellent "barometer" of overall cardiovascular risk (eg, the likelihood of cardiac angina, myocardial infarction, stroke, or peripheral vascular disease) ${ }^{89}$ Multiple studies have demonstrated that the presence of endothelial dysfunction in large conduit vessels, coronary arteries, and resistance arterioles predicts future cardiovascular events in humans both with and without prevalent coronary artery disease. ${ }^{46,90}$ Pharmacological interventions targeting cardiovascular risk factors are more efficacious when they concomitantly reduce cardiovascular risk. ${ }^{91,92}$

While the clinical application of measurements of endothelial function remains limited, ${ }^{46,90}$ these data strongly support the concept that readily measureable endothelial function provides key information on overall cardiovascular health. In the following sections, we will discuss the role of endothelial structural elements that influence overall endothelial function.

\section{Relationships between endothelial structural elements and endothelial function \\ Glycocalyx}

The endothelium is in direct contact with the blood's fluid; cellular components (erythrocytes, leukocytes, and platelets); macromolecules such as lipids; proteins and carbohydrates; and small molecules such as water, glucose, and ions. Under normal homeostatic conditions, blood components that stimulate vascular inflammation, injury, and thrombus formation generally do not adhere to endothelial cells. This biological feature is, at least in part, attributable to an anti-inflammatory and anti-thrombogenic surface on the endothelium, the glycocalyx. ${ }^{93}$ The glycocalyx is a uniform, semipermeable layer (on average $\sim 50$ to $100 \mathrm{~nm}$ thick) composed of proteins, glycoproteins, glycolipids, and proteoglycans. ${ }^{12}$ The net electrostatic charge of the glycocalyx is negative at physiological $\mathrm{pH}$ level $\mathrm{s}^{93-95}$ due to heparin-like sulfated mucopolysaccharides and neuraminidase-sensitive (or -resistant) anionic groups within the layer. ${ }^{95-97}$ Because of electrostatic repulsion, negatively charged erythrocytes, leukocytes, and low-density lipoprotein (LDL) cholesterol are repelled from the surface of the endothelium, inhibiting attachment to the endothelium. ${ }^{94,98}$ This repulsion results in an erythrocyte-free plasma layer along the endothelium, decreasing hemoglobin-scavenging of $\mathrm{NO}$ and preserving overall endothelial NO bioavailability. ${ }^{99}$

The glycocalyx is organized by core proteins in the proteoglycan clusters and these proteins attach to the intracellular cortical cytoskeleton bridged to integrin-containing focal adhesion molecules in the extracellular matrix by alpha actinin and actin stress fibers. ${ }^{98}$ The structural relationship between the glycocalyx and the cellular cytoskeleton appears to require co-localization of integrin with syndecan- $4 .{ }^{100,101}$ Syndecan-4, a trans-membrane protein, connects with the cytoskeleton by its cytoplasmic tail and participates in cytoskeleton organization via mechanotransduction. ${ }^{102}$

The mesh network of the glycocalyx works as a molecular sieve to adsorb plasma protein molecules such as albumin, fibronectin, and fibrinogen. This helps to establish an elastic interface that can withstand the mechanical forces to which it is subjected to by pulsatile blood flow. ${ }^{12,93,103}$ The hydraulic 
resistance of the glycocalyx and its matrix is approximately 108 1011 dyn s/cm ${ }^{4}{ }^{12}$

Many pathological factors, such as oxLDL, salt-sensitive hypertension, and diabetes have been shown to be able to disturb the anionic charge, structure, and distribution of the glycocalyx. ${ }^{95,104,105}$ This leads to increased cell permeability and recruitment of pro-inflammatory and pro-atherogenic factors. ${ }^{95}$ Excessive oxidative stress mechanistically contributes to hypoxia and hyperlipidemia disrupts the glycocalyx. ${ }^{95,106}$ Further, reduced heparin sulfate in the glycocalyx, secondary to excessive oxidative stress, reduces transport of L-arginine to the endothelial surface, leading to a decrease in NO production.

\section{Cell-cell junctions}

While our appreciation of the potential role alterations in the glycocalyx may play in the development of endothelial dysfunction continues to grow, other extracellular structures in particular, cell-cell junctions - also play an important role in regulating endothelial function. Cell-cell junctions are critical to the maintenance of normal endothelial cell barrier functions and mediate intercellular signaling conduction. The three types of junctions between endothelial cells include tight, gap, and adherence. The protein components of tight junctions are zonula occludens 1, cingulin, and a small guanosine triphosphate-binding protein, rab 13. These molecules mediate intracellular signal transduction by anchoring tight junctions to actin microfilaments. ${ }^{3}$ Gap junctions are composed of connexins (Cx37, Cx40, Cx43), while adherence junctions consist of cadherins and cytoskeletal proteins $\alpha$-catenin and $\beta$-catenin vinculin, and plakoglobin. ${ }^{9,107}$ Tight junctions seal off paracellular clefts to limit intercellular permeability. Phosphorylation of zonula occludens 1 increases vascular permeability, a mechanism involved in diabetic vasculopathy. ${ }^{9,108}$ The primary role of gap junctions is to mediate electrochemical signaling via low-resistance conduction pathways - these signals govern cell migration and replication. ${ }^{3,19,109,110}$ Gap junctions may play an important role in endothelium-dependent vasodilation and blood pressure regulation. ${ }^{111,112}$ Reduced connexin levels in gap junctions are found in hypertensive and diabetic animals with phenotypical endothelial dysfunction. ${ }^{12,113}$ In adherence junctions, cadherin connects with catenin via its cytoplasmic domain, forming a cadherin-catenin complex. These complexes anchor to actin microfilaments of the cytoskeleton to mediate cell-cell interaction. ${ }^{3,9}$

In addition to the three types of junctions delineated above, platelet-endothelial adhesion molecule 1 (PECAM-1), an endothelial adhesive molecule belonging to the immunoglobulin family, also participates in endothelial cell-cell recognition, cell junction assembly, and leukocyte extravasation. ${ }^{3,9}$ PECAM-1 participates in modulating NO signaling by mediating shear stress-induced phosphorylation of eNOS and Akt enzymes in endothelial cells. ${ }^{114}$ Another endothelial adhesive molecule, integrin, helps anchor endothelial cells onto the extracellular matrix, playing a critical role in maintaining endothelial cell permeability. ${ }^{3,115}$ Integrins also mediate shear-induced signaling transduction via the Src/ extracellular signal-regulated kinase/phosphatidylinositol 3-kinase pathway or by inducing PECAM-1 tyrosine phosphorylation. ${ }^{116}$

\section{Cytoskeleton}

The endothelium is subjected to multiple mechanical forces, including laminar shear stress, cyclic strain, hydrostatic pressure, and pulsatile pressure. ${ }^{117}$ To maintain structural integrity, the endothelium must be resilient enough to withstand these stressors. In concert with the glycocalyx and intercellular junctions, ${ }^{12,93}$ the endothelial cell cytoskeleton plays a central role in maintaining cellular structural integrity and transducing cellular responses to mechanical forces. ${ }^{9,94,95,98,118,119}$

The endothelial cytoskeleton is composed of three types of filaments: microfilaments, microtubules, and intermediate filaments. ${ }^{118}$ Of these, microfilaments and microtubules appear to be the most important in regulating endothelial cell structure and function. Microfilaments (200-500 nm diameter) are comprised of a contractile protein, actin, either in monomeric form (globular or G-actin) or filamentous form (F-actin). Actin microfilaments form dense peripheral bands in the cell periphery and stress fibers in the central portions of endothelial cells. ${ }^{118}$ Actin microfilaments can change their orientation, distribution, and alignment based on the type of shear exposure. For example, in high laminar shear states, actin forms more prominent central bands than under low laminar shear states. ${ }^{118}$ Under turbulent flow, cytoskeletal remodeling promotes the atherosclerotic processes by altering the endothelial architecture and molecular responses toward favoring endothelial dysfunction. ${ }^{17}$ Vascular inflammation is associated with endothelial cytoskeletal redistribution leading to increased intercellular gap size and paracellular permeability. ${ }^{118}$ Actin fibers attach to integrins on the cytoplasmic side of the cell surface, allowing microfilaments to participate in integrin-mediated signaling that may result in cell-cell adhesion, cell differentiation, and cell proliferation..$^{45,120}$ Microtubules are formed by tubulin 
heterodimers of $\alpha$ and $\beta$ subunits $^{121}$ and are distributed throughout the cytoplasm. Microtubules play a major role in the transportation of intracellular vesicles and localization of membrane-bound organelles. Functioning microtubules are essential for maintaining shear-induced NO production ${ }^{122}$ and vasodilation. ${ }^{123}$

Common cardiovascular risk factors known to reduce NO bioavailability, including hyperlipidemia, hypertension, diabetes, and smoking, ${ }^{46}$ alter microfilament structure and distribution. ${ }^{124-127} \mathrm{NO}$ inhibition changes the distribution of actin filaments in endothelial cells, while shear alters actin orientation in an NO-dependent manner. ${ }^{44,128}$ As a major component of ribonucleoprotein binding with eNOS mRNA untranslated region, G-actin increases eNOS mRNA instability. Therefore, lower G-/F-actin ratios are associated with a higher eNOS expression. ${ }^{129}$ This regulation of eNOS expression by actin may be clinically important in limiting neurological damage from strokes. ${ }^{130}$ Endothelial nuclear $\beta$-actin appears to upregulate eNOS expression by binding onto the $27 \mathrm{nt}$ repeat element of eNOS, intron $4,{ }^{131}$ which suppresses eNOS expression via histone acetylation and DNA methylation. ${ }^{132}$

Intact microtubules are important in maintaining eNOS activity in pulmonary vascular endothelial cells ${ }^{133}$ and NO-dependent vasodilation in other key arterial beds. ${ }^{134}$ Microtubules may exert their regulatory influence on eNOS by altering cellular distribution of proteins and co-factors directly related to NO production, including arginase. ${ }^{122}$ oxLDL may increase arginase activity by disrupting microtubules, which may in part account for reduced NO bioavailability in hypercholesterolemia. ${ }^{135}$ Angiotensin II, commonly elevated in hypertension and endothelial dysfunction, ${ }^{136}$ induces microtubule disassembly. ${ }^{137}$ Adiponectin, an adipocyte chemokine that is suppressed in obesity, protects the endothelium against inflammatory stimuli partly by reducing microtubule disassembly, as well as through protecting gap junctions and actin fibers. ${ }^{138}$ Taken together, these data strongly suggest microtubule disassembly, induced by common cardiovascular risk factors, is an important event in the development of endothelial dysfunction.

\section{Involvement of cytoskeletal elements in flow-induced endothelial cell signaling}

As discussed previously, the endothelial cytoskeleton is deeply interconnected with the cell surface, cell junctions, and focal adhesion molecules. An intact cytoskeleton appears to be central to flow-induced signaling, particularly the eNOSdependent NO production vital to endothelium-dependent vasodilation in multiple vascular beds. Experimental disruption of microtubule structure in isolated rat arterioles leads to an impaired flow-mediated dilation. ${ }^{123}$ Inhibition of both actin filaments and microtubules interferes with vasodilatory signaling in human coronary arterioles and the pulmonary circulation, ${ }^{139-141}$ suggesting the importance of the integrity of endothelial cytoskeleton in regulating endothelial-dependent vasodilator signaling transduction.

Multiple mechanisms are responsible for the intrinsic connection between cytoskeletal elements and NO-dependent vasodilation. First, shear-induced increases in intracellular calcium require intact actin microfilaments. ${ }^{107,142}$ An intact cytoskeleton may also be important in shear-induced, Aktdependent phosphorylation/activation of eNOS. ${ }^{143,144}$ Laminar shear increases NO production by increasing eNOS-heat

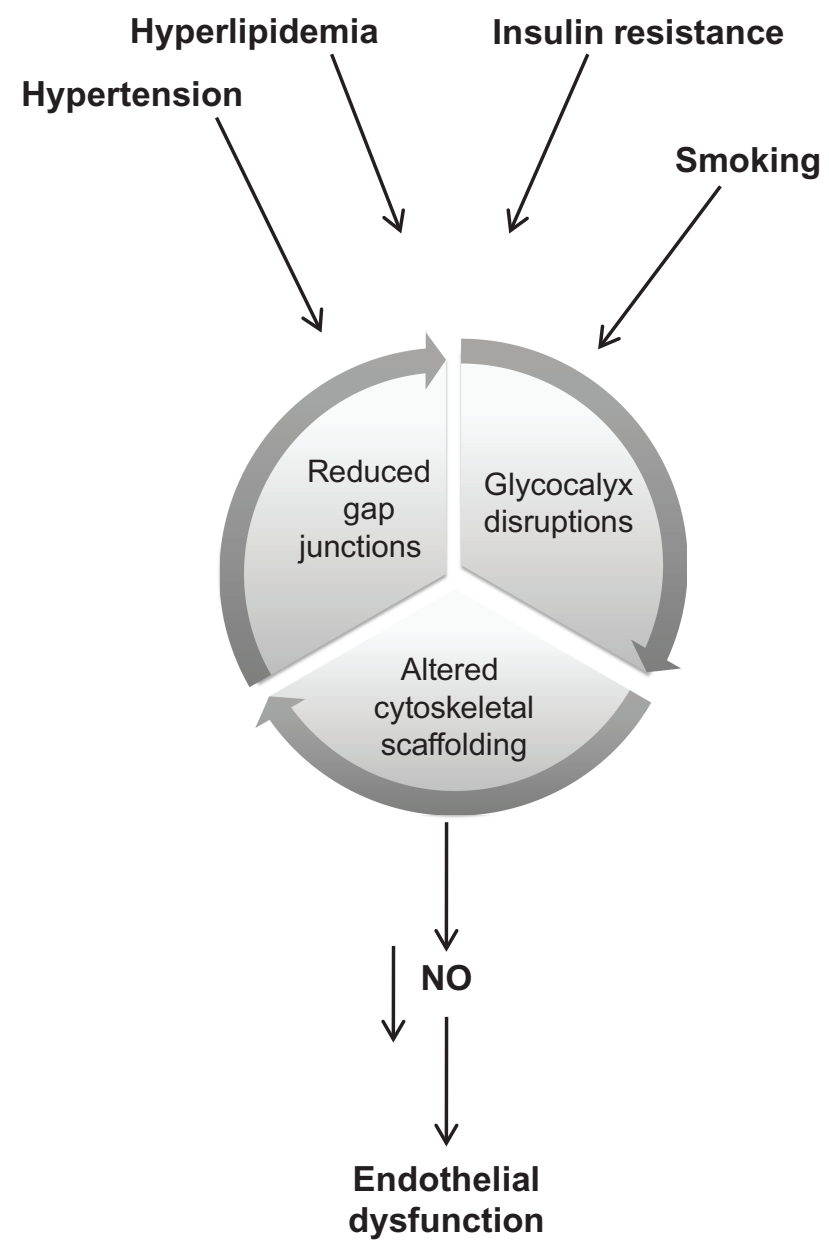

Figure I Traditional cardiovascular risk factors induce alterations in endothelial cell structure associated with impaired nitric oxide (NO) bioavailability and subsequent endothelial dysfunction.

Notes: Traditional cardiovascular risk factors alter the endothelial cell surface, cell-cell adhesion molecules, and the cytoskeleton, which appear mechanistically important in suppressing NO bioavailability and subsequent endothelial dysfunction. 
shock protein ${ }^{90}$ interactions required for NO production. This interaction is stabilized by both tubulin and actin microfilaments. ${ }^{143}$ Shear stress-induced reorganization of the cytoskeleton may influence eNOS activity and NO production by regulating eNOS-caveolin-1-actin filament associations. $^{145}$

Downstream transmission of shear signaling appears to be mechanistically linked to modulation of mitochondrial ROS production and the motion of the nuclear karyoskeleton. ${ }^{107}$ Actin transmits shear stretch signals to mitochondria, triggering the release of mitochondrial ROS production, activation of nuclear factor kappa $B,{ }^{140,146}$ and reduction of NO bioavailability that occur concomitantly with mitochondrial inner membrane hyperpolarization. ${ }^{147}$ Through interaction with $\mathrm{p} 47$ phox, the actin cytoskeleton in endothelial cells also plays a role in regulating the NADPH oxidase-derived ROS level during shear-induced reorganization. ${ }^{148}$ Taken together with our knowledge of the mechanistic links between NO and cytoskeletal elements, the concept of coordinate regulation between cytoskeletal elements and traditional endothelial cell signaling cascades responsible for endothelial function is well supported.

\section{Conclusion}

Overall, the current data support the concept that the endothelium's "form" mirrors its "function." Traditional cardiovascular risk factors known to affect vascular signaling leading to endothelial dysfunction also have characteristic effects on endothelial cell structure (Figure 1). Further, vascular endothelial cell signaling, particularly in relation to shear, appears intrinsically related to the endothelial cell surface, cell-cell interactions, and cytoskeletal elements. These data also suggest that the endothelial cell structural components could be potential targets for pharmacological therapies to improve vascular homeostasis. Significant work remains to be done to unravel how key vascular regulators such NO are mechanistically linked to cytoskeletal and other cell structural components and this information can be best used to improve cardiovascular health.

\section{Disclosure}

The authors report no conflicts of interest in this work.

\section{References}

1. Altschul R. Endothelium: its development, morphology, function, and pathology. New York, NY: Macmillan; 1954.

2. Laubicher MD, Aird WC, Maienschein J. The endothelium in history. In: Aird WC, editor. Endothelial Biomedicine. New York, NY: Cambridge University Press; 2007:5-19.
3. Dejana E, Corada M, Lampugnani MG. Endothelial cell-to-cell junctions. FASEB J. 1995;9(10):910-918.

4. Dimmeler S, Hermann C, Zeiher AM. Apoptosis of endothelial cells. Contribution to the pathophysiology of atherosclerosis? Eur Cytokine Netw. 1998;9(4):697-698.

5. Fry DL. Acute vascular endothelial changes associated with increased blood velocity gradients. Circ Res. 1968;22(2):165-197.

6. Galley HF, Webster NR. Physiology of the endothelium. British $J$ Anaesth. 2004;93(1):105-113.

7. Hagberg CE, Falkevall A, Wang X, et al. Vascular endothelial growth factor B controls endothelial fatty acid uptake. Nature. 2010; 464(7290):917-921.

8. Lamping $\mathrm{K}$. Interactions between NO and cAMP in the regulation of vascular tone. Arterioscler Thromb Vasc Biol. 2001;21(5):729-730.

9. Lampugnani MG, Caveda L, Breviario F, Del Maschio A, Dejana E. Endothelial cell-to-cell junctions. Structural characteristics and functional role in the regulation of vascular permeability and leukocyte extravasation. Baillieres Clin Haematol. 1993;6(3):539-558.

10. Li JM, Shah AM. Endothelial cell superoxide generation: regulation and relevance for cardiovascular pathophysiology. Am J Physiol Regul Integr Comp Physiol. 2004;287(5):R1014-R1030.

11. Liu J, García-Cardeña G, Sessa WC. Palmitoylation of endothelial nitric oxide synthase is necessary for optimal stimulated release of nitric oxide: implications for caveolae localization. Biochemistry. 1996; 35(41):13277-13281.

12. Pries AR, Secomb TW, Gaehtgens P. The endothelial surface layer. Pflugers Arch. 2000;440(5):653-666.

13. Wong MK, Gotlieb AI. Endothelial cell monolayer integrity. I. Characterization of dense peripheral band of microfilaments. Arteriosclerosis. 1986;6(2):212-219.

14. Félétou M. The endothelium. Part 1: multiple functions of the endothelial cells - focus on endothelium-derived vasoactive mediators. In: Granger DN, Granger JP, editors. Colloquium Series on Integrated Systems Physiology: From Molecule to Function to Disease. San Rafael: Morgan and Claypool Life Sciences; 2011. Available from: http://www. ncbi.nlm.nih.gov/books/NBK57149/. Accessed September 16, 2012.

15. Palade GE. Blood capillaries of the heart and other organs. Circulation. 1961;24:368-388.

16. Levick JR. The endothelial cell. In: An Introduction to Cardiovascular Physiology. 5th ed. 147-165. London: Hodder Arnold; 2010.

17. Damani S, Bacconi A, Libiger O, et al. Characterization of circulating endothelial cells in acute myocardial infarction. Sci Transl Med. 2012; 4(126): $126 \mathrm{ra33}$

18. Tokunaga O, Fan JL, Watanabe T. Atherosclerosis- and age-related multinucleated variant endothelial cells in primary culture from human aorta. Am J Pathol. 1989;135(6):967-976.

19. Vuong PN, Berry C. The Pathology of Vessels. Springer, Springer-Verlag France, Paris 2002.

20. Hazel AL, Pedley TJ. Vascular endothelial cells minimize the total force on their nuclei. Biophys J. 2000;78(1):47-54.

21. Jaffe EA, Nachman RL, Becker CG, Minick CR. Culture of human endothelial cells derived from umbilical veins. Identification by morphologic and immunologic criteria. J Clin Invest. 1973;52(11): 2745-2756.

22. Catravas JD, Snead C, Dimitropoulou C, et al. Harvesting, identification and barrier function of human lung microvascular endothelial cells. Vascul Pharmacol. 2010;52(5-6):175-181.

23. You L, Wu M, Chen Y, et al. Isolation and characterization of lymphatic endothelial cells from human glossal lymphangioma. Oncol Rep. 2010; 23(1):105-111.

24. Aird WC. Mechanisms of endothelial cell heterogeneity in health and disease. Circ Res. 2006;98(2):159-162.

25. Furchgott RF, Zawadzki JV. The obligatory role of endothelial cells in the relaxation of arterial smooth muscle by acetylcholine. Nature. 1980;288(5789):373-376.

26. Panza JA, Cannon RO. Endothelium, Nitric Oxide, and Atherosclerosis. Futura Publishing Company, Inc. Armonk, NY 1999. 
27. Palmer RM, Ferrige AG, Moncada S. Nitric oxide release accounts for the biological activity of endothelium-derived relaxing factor. Nature. 1987;327(6122):524-526.

28. Godfraind T. EDRF and cyclic GMP control gating of receptor-operated calcium channels in vascular smooth muscle. Eur J Pharmacol. 1986; 126(3):341-343.

29. Murad F, Waldman S, Molina C, Bennett B, Leitman D. Regulation and role of guanylate cyclase-cyclic GMP in vascular relaxation. Prog Clin Biol Res. 1987;249:65-76.

30. Twort $\mathrm{CH}$, van Breemen C. Cyclic guanosine monophosphate-enhanced sequestration of $\mathrm{Ca} 2+$ by sarcoplasmic reticulum in vascular smooth muscle. Circ Res. 1988;62(5):961-964.

31. Wang J, Widlansky ME. Lifestyle choices and endothelial function: risk and relevance. Current Vasc Pharmacol. 2009;7(2):209-224.

32. Wang Y, Heilig KO, Minto AW, et al. Nephron-deficient Fvb mice develop rapidly progressive renal failure and heavy albuminuria involving excess glomerular GLUT1 and VEGF. Lab Invest. 2009;90(1): 83-97.

33. Zhou M, Liu Z, Wei Z, et al. Development and validation of smalldiameter vascular tissue from a decellularized scaffold coated with heparin and vascular endothelial growth factor. Artif Organs. 2009; 33(3):230-239.

34. Levine GN, Keaney JF Jr, Vita JA. Cholesterol reduction in cardiovascular disease. Clinical benefits and possible mechanisms. N Engl J Med. 1995;332(8):512-521.

35. Bhagat K, Moss R, Collier J, Vallance P. Endothelial “stunning” following a brief exposure to endotoxin: a mechanism to link infection and infarction? Cardiovasc Res. 1996;32(5):822-829.

36. Fichtlscherer S, Rosenberger G, Walter DH, Breuer S, Dimmeler S, Zeiher AM. Elevated C-reactive protein levels and impaired endothelial vasoreactivity in patients with coronary artery disease. Circulation. 2000;102(9):1000-1006

37. Hingorani AD, Cross J, Kharbanda RK, et al. Acute systemic inflammation impairs endothelium-dependent dilatation in humans Circulation. 2000;102(9):994-999.

38. Cines DB, Pollak ES, Buck CA, et al. Endothelial cells in physiology and in the pathophysiology of vascular disorders. Blood. 1998;91(10): 3527-3561.

39. De Caterina R, Libby P, Peng HB, et al. Nitric oxide decreases cytokine-induced endothelial activation. Nitric oxide selectively reduces endothelial expression of adhesion molecules and proinflammatory cytokines. J Clin Invest. 1995;96(1):60-68.

40. Tomita H, Egashira K, Kubo-Inoue M, et al. Inhibition of NO synthesis induces inflammatory changes and monocyte chemoattractant protein-1 expression in rat hearts and vessels. Arterioscler Thromb Vasc Biol. 1998;18(9):1456-1464.

41. Qian H, Neplioueva V, Shetty GA, Channon KM, George SE. Nitric oxide synthase gene therapy rapidly reduces adhesion molecule expression and inflammatory cell infiltration in carotid arteries of cholesterol-fed rabbits. Circulation. 1999;99(23):2979-2982.

42. Tsao PS, McEvoy LM, Drexler H, Butcher EC, Cooke JP. Enhanced endothelial adhesiveness in hypercholesterolemia is attenuated by L-arginine. Circulation. 1994;89(5):2176-2182.

43. Zeiher AM, Fisslthaler B, Schray-Utz B, Busse R. Nitric oxide modulates the expression of monocyte chemoattractant protein 1 in cultured human endothelial cells. Circ Res. 1995;76(6): 980-986.

44. Baldwin AL, Thurston G, al Naemi H. Inhibition of nitric oxide synthesis increases venular permeability and alters endothelial actin cytoskeleton. Am J Physiol. 1998;274:H1776-H1784.

45. Lee TY, Gotlieb AI. Microfilaments and microtubules maintain endothelial integrity. Microsc Res Tech. 2003;60(1):115-127.

46. Widlansky ME, Gokce N, Keaney JF Jr, Vita JA. The clinical implications of endothelial dysfunction. J Am Coll Cardiol. 2003;42(7): 1149-1160.

47. Loscalzo J. Nitric oxide insufficiency, platelet activation, and arterial thrombosis. Circ Res. 2001;88(8):756-762.
48. Freedman JE, Loscalzo J, Barnard MR, Alpert C, Keaney JF, Michelson AD. Nitric oxide released from activated platelets inhibits platelet recruitment. J Clin Invest. 1997;100(2):350-356.

49. Michelson AD, Benoit SE, Furman MI, et al. Effects of nitric oxide/ EDRF on platelet surface glycoproteins. Am J Physiol. 1996;270(5 Pt 2): H1640-H1648.

50. Bouchie JL, Hansen H, Feener EP. Natriuretic factors and nitric oxide suppress plasminogen activator inhibitor-1 expression in vascular smooth muscle cells. Role of cGMP in the regulation of the plasminogen system. Arterioscler Thromb Vasc Biol. 1998;18(11):1771-1779.

51. Esmon CT. The roles of protein $\mathrm{C}$ and thrombomodulin in the regulation of blood coagulation. J Biol Chem. 1989;264(9):4743-4746.

52. Preston RA, Jy W, Jimenez JJ, et al. Effects of severe hypertension on endothelial and platelet microparticles. Hypertension. 2003;41(2): 211-217.

53. Landmesser U, Dikalov S, Price SR, et al. Oxidation of tetrahydrobiopterin leads to uncoupling of endothelial cell nitric oxide synthase in hypertension. J Clin Invest. 2003;111(8):1201-1209.

54. Dohi Y, Hahn AW, Boulanger CM, Bühler FR, Lüscher TF. Endothelin stimulated by angiotensin II augments contractility of spontaneously hypertensive rat resistance arteries. Hypertension. 1992;19(2): $131-137$.

55. Hitomi H, Kiyomoto H, Nishiyama A. Angiotensin II and oxidative stress. Curr Opin Cardiol. 2007;22(4):311-315.

56. Panza JA, Quyyumi AA, Brush JE Jr, Epstein SE. Abnormal endothelium-dependent vascular relaxation in patients with essential hypertension. N Engl J Med. 1990;323(1):22-27.

57. Panza JA, Casino PR, Kilcoyne CM, Quyyumi AA. Role of endothelium-derived nitric oxide in the abnormal endotheliumdependent vascular relaxation of patients with essential hypertension. Circulation. 1993;87(5):1468-1474.

58. Huang PL, Huang Z, Mashimo $\mathrm{H}$, et al. Hypertension in mice lacking the gene for endothelial nitric oxide synthase. Nature. 1995; 377(6546): $239-242$.

59. Williams SB, Cusco JA, Roddy MA, Johnstone MT, Creager MA. Impaired nitric oxide-mediated vasodilation in patients with noninsulin-dependent diabetes mellitus. J Am Coll Cardiol. 1996;27(3): $567-574$.

60. Williams SB, Goldfine AB, Timimi FK, et al. Acute hyperglycemia attenuates endothelium-dependent vasodilation in humans in vivo. Circulation. 1998;97(17):1695-1701.

61. Yamauchi T, Ohnaka K, Takayanagi R, Umeda F, Nawata H. Enhanced secretion of endothelin-1 by elevated glucose levels from cultured bovine aortic endothelial cells. FEBS Lett. 1990;267(1):16-18.

62. Davel AP, Wenceslau CF, Akamine EH, et al. Endothelial dysfunction in cardiovascular and endocrine-metabolic diseases: an update. Braz J Med Biol Res. 2011;44(9):920-932.

63. Bagi Z, Toth E, Koller A, Kaley G. Microvascular dysfunction after transient high glucose is caused by superoxide-dependent reduction in the bioavailability of $\mathrm{NO}$ and BH(4). Am J Physiol Heart Circ Physiol. 2004;287(2):H626-H633.

64. Cai S, Khoo J, Channon KM. Augmented BH4 by gene transfer restores nitric oxide synthase function in hyperglycemic human endothelial cells. Cardiovasc Res. 2005;65(4):823-831.

65. Mohanty P, Hamouda W, Garg R, Aljada A, Ghanim H, Dandona P. Glucose challenge stimulates reactive oxygen species (ROS) generation by leucocytes. J Clin Endocrinol Metab. 2000;85(8):2970-2973.

66. Schulze PC, Yoshioka J, Takahashi T, He Z, King GL, Lee RT. Hyperglycemia promotes oxidative stress through inhibition of thioredoxin function by thioredoxin-interacting protein. J Biol Chem. 2004;279(29):30369303-30369374.

67. Brownlee M. Biochemistry and molecular cell biology of diabetic complications. Nature. 2001;414(6865):813-820.

68. Yu T, Robotham JL, Yoon Y. Increased production of reactive oxygen species in hyperglycemic conditions requires dynamic change of mitochondrial morphology. Proc Natl Acad Sci U S A. 2006;103(8): 2653-2658. 
69. Yu T, Sheu SS, Robotham JL, Yoon Y. Mitochondrial fission mediates high glucose-induced cell death through elevated production of reactive oxygen species. Cardiovasc Res. 2008;79(2):341-351.

70. Cox DA, Vita JA, Treasure CB, et al. Atherosclerosis impairs flowmediated dilation of coronary arteries in humans. Circulation. 1989; 80(3):458-465.

71. Creager MA, Cooke JP, Mendelsohn ME, et al. Impaired vasodilation of forearm resistance vessels in hypercholesterolemic humans. J Clin Invest. 1990;86(1):228-234.

72. Egashira K, Inou T, Hirooka Y, et al. Impaired coronary blood flow response to acetylcholine in patients with coronary risk factors and proximal atherosclerotic lesions. J Clin Invest. 1993;91(1):29-37.

73. Ludmer PL, Selwyn AP, Shook TL, et al. Paradoxical vasoconstriction induced by acetylcholine in atherosclerotic coronary arteries. $N$ Engl J Med. 1986;315(17):1046-1051.

74. Stewart DJ, Monge JC. Hyperlipidemia and endothelial dysfunction. Curr Opin Lipidol. 1993;4:319-324.

75. Vita JA, Treasure CB, Nabel EG, et al. Coronary vasomotor response to acetylcholine relates to risk factors for coronary artery disease. Circulation. 1990;81(2):491-497.

76. Li H, Förstermann U. Prevention of atherosclerosis by interference with the vascular nitric oxide system. Curr Pharm Des. 2009;15(27): 3133-3145.

77. Vásquez-Vivar J, Kalyanaraman B, Martásek P. The role of tetrahydrobiopterin in superoxide generation from eNOS: enzymology and physiological implications. Free Radic Res. 2003;37(2): 121-127.

78. Meininger CJ, Marinos RS, Hatakeyama K, et al. Impaired nitric oxide production in coronary endothelial cells of the spontaneously diabetic BB rat is due to tetrahydrobiopterin deficiency. Biochem J. 2000;349(Pt 1): 353-356.

79. Tiefenbacher CP. Tetrahydrobiopterin: a critical cofactor for eNOS and a strategy in the treatment of endothelial dysfunction? Am J Physiol Heart Circ Physiol. 2001;280(6):H2484-H2488.

80. Fukuda Y, Teragawa H, Matsuda K, Yamagata T, Matsuura H, Chayama K. Tetrahydrobiopterin restores endothelial function of coronary arteries in patients with hypercholesterolaemia. Heart. 2002;87(3):264-269.

81. Maier W, Cosentino F, Lütolf RB, et al. Tetrahydrobiopterin improves endothelial function in patients with coronary artery disease. J Cardiovasc Pharmacol. 2000;35(2):173-178.

82. Stroes E, Kastelein J, Cosentino F, et al. Tetrahydrobiopterin restores endothelial function in hypercholesterolemia. J Clin Invest. 1997; 99(1):41-46.

83. Böger RH, Bode-Böger SM, Szuba A, et al. Asymmetric dimethylarginine (ADMA): a novel risk factor for endothelial dysfunction: its role in hypercholesterolemia. Circulation. 1998;98(18):1842-1847.

84. Miyazaki H, Matsuoka H, Cooke JP, et al. Endogenous nitric oxide synthase inhibitor: a novel marker of atherosclerosis. Circulation. 1999; 99(9):1141-1146.

85. Feron O, Dessy C, Moniotte S, Desager JP, Balligand JL. Hypercholesterolemia decreases nitric oxide production by promoting the interaction of caveolin and endothelial nitric oxide synthase. J Clin Invest. 1999;103(6):897-905.

86. Vasile E, Antohe F. An ultrastructural study of beta-very low density lipoprotein uptake and transport by valvular endothelium of hyperlipidemic rabbits. J Submicrosc Cytol Pathol. 1991;23(2):279-287.

87. Li H, Cybulsky MI, Gimbrone MA Jr, Libby P. An atherogenic diet rapidly induces VCAM-1, a cytokine-regulatable mononuclear leukocyte adhesion molecule, in rabbit aortic endothelium. Arterioscler Thromb Vasc Biol. 1993;13(2):197-204.

88. Libby P. Inflammation and cardiovascular disease mechanisms. Am J Clin Nutr. 2006;83:456S-460S.

89. Vita JA, Keaney JF Jr. Endothelial function: a barometer for cardiovascular risk? Circulation. 2002;106(6):640-642.

90. Thijssen DH, Black MA, Pyke KE, et al. Assessment of flow-mediated dilation in humans: a methodological and physiological guideline. Am J Physiol Heart Circ Physiol. 2011;300(1):H2-H12.
91. Kitta Y, Obata JE, Nakamura T, et al. Persistent impairment of endothelial vasomotor function has a negative impact on outcome in patients with coronary artery disease. J Am Coll Cardiol. 2009;53(4):323-330.

92. Modena MG, Bonetti L, Coppi F, Bursi F, Rossi R. Prognostic role of reversible endothelial dysfunction in hypertensive postmenopausal women. J Am Coll Cardiol. 2002;40(3):505-510.

93. Squire JM, Chew M, Nneji G, Neal C, Barry J, Michel C. Quasi-periodic substructure in the microvessel endothelial glycocalyx: a possible explanation for molecular filtering? J Struct Biol. 2001; 136(3):239-255.

94. Vink H, Duling BR. Capillary endothelial surface layer selectively reduces plasma solute distribution volume. Am J Physiol Heart Circ Physiol. 2000;278(1):H285-H289.

95. Pelikan P, Gimbrone MA Jr, Cotran RS. Distribution and movement of anionic cell surface sites in cultured human vascular endothelial cells. Atherosclerosis. 1979;32(1):69-80.

96. Simionescu M, Simionescu N, Palade GE. Biochemically differentiated microdomains of the cell surface of capillary endothelium. Ann NY Acad Sci. 1982;401:9-24.

97. Buonassisi V, Root M. Enzymatic degradation of heparin-related mucopolysaccharides from the surface of endothelial cell cultures. Biochim Biophys Acta. 1975;385(1):1-10.

98. Weinbaum S, Zhang X, Han Y, Vink H, Cowin SC. Mechanotransduction and flow across the endothelial glycocalyx. Proc Natl Acad Sci USA. 2003;100(13):7988-7995.

99. Chen X, Jaron D, Barbee KA, Buerk DG. The influence of radial RBC distribution, blood velocity profiles, and glycocalyx on coupled $\mathrm{NO}$ / O2 transport. J Appl Physiol. 2006;100(2):482-492.

100. Greene DK, Tumova S, Couchman JR, Woods A. Syndecan-4 associates with alpha-actinin. J Biol Chem. 2003;278(9):7617-7623.

101. Saoncella S, Echtermeyer F, Denhez F, et al. Syndecan-4 signals cooperatively with integrins in a Rho-dependent manner in the assembly of focal adhesions and actin stress fibers. Proc Natl Acad Sci US A. 1999;96(6):2805-2810.

102. Tkachenko E, Rhodes JM, Simons M. Syndecans: new kids on the signaling block. Circ Res. 2005;96(5):488-500.

103. van den Berg BM, Nieuwdorp M, Sroes E, Vink H. Endothelial luminal glycocalyx: protective barrier between endothelial cells and flowing blood. In: Aird WC, editor. Endothelial Biomedicine. New York, NY: Cambridge University Press; 2007:689-695.

104. Raz I, Havivi Y, Yarom R. Reduced negative surface charge on arterial endothelium of diabetic rats. Diabetologia. 1988;31(8):618-620.

105. Oberleithner H, Peters W, Kusche-Vihrog K, et al. Salt overload damages the glycocalyx sodium barrier of vascular endothelium. Pflugers Arch. 2011;462(4):519-528.

106. Weinbaum S, Tarbell JM, Damiano ER. The structure and function of the endothelial glycocalyx layer. Annu Rev Biomed Eng. 2007;9: 121-167.

107. Helmke BP, Davies PF. The cytoskeleton under external fluid mechanical forces: hemodynamic forces acting on the endothelium. Ann Biomed Eng. 2002;30(3):284-296.

108. Antonetti DA, Barber AJ, Hollinger LA, Wolpert EB, Gardner TW. Vascular endothelial growth factor induces rapid phosphorylation of tight junction proteins occludin and zonula occluden 1. A potential mechanism for vascular permeability in diabetic retinopathy and tumors. J Biol Chem. 1999;274(33):23463-23467.

109. de Wit C, Hoepfl B, Wölfle SE. Endothelial mediators and communication through vascular gap junctions. Biol Chem. 2006; 387(1):3-9.

110. Hill CE, Rummery N, Hickey H, Sandow SL. Heterogeneity in the distribution of vascular gap junctions and connexins: implications for function. Clin Exp Pharmacol Physiol. 2002;29(7):620-625.

111. Hammond S, Mathewson AM, Baker PN, Mayhew TM, Dunn WR. Gap junctions and hydrogen peroxide are involved in endotheliumderived hyperpolarising responses to bradykinin in omental arteries and veins isolated from pregnant women. Eur J Pharmacol. 2011; 668(1-2):225-232. 
112. Rummery NM, Hill CE. Vascular gap junctions and implications for hypertension. Clin Exp Pharmacol Physiol. 2004;31(10):659-667.

113. Makino A, Platoshyn O, Suarez J, Yuan JX, Dillmann WH. Downregulation of connexin 40 is associated with coronary endothelial cell dysfunction in streptozotocin-induced diabetic mice. Am J Physiol Cell Physiol. 2008;295(1):C221-C230.

114. Fleming I, Fisslthaler B, Dixit M, Busse R. Role of PECAM-1 in the shear-stress-induced activation of Akt and the endothelial nitric oxide synthase (eNOS) in endothelial cells. J Cell Sci. 2005;118(Pt 18): 4103-4111.

115. Muller JM, Chilian WM, Davis MJ. Integrin signaling transduces shear stress - dependent vasodilation of coronary arterioles. Circ Res. 1997; 80(3):320-326.

116. Langille BL. Morphologic responses of endothelium to shear stress reorganization of the adherens junction. Microcirculation. 2001, 8(3):195-206.

117. Oluwole BO, Du W, Mills I, Sumpio BE. Gene regulation by mechanical forces. Endothelium. 1997;5(2):85-93.

118. Gottlieb AI, Langille BL, Wong MK, Kim DW. Structure and function of the endothelial cytoskeleton. Lab Invest. 1991;65(2):123-137.

119. Hardebo JE, Kåhrström J. Endothelial negative surface charge areas and blood-brain barrier function. Acta Physiol Scand. 1985;125:495-499.

120. Schoenwaelder SM, Burridge K. Bidirectional signaling between the cytoskeleton and integrins. Curr Opin Cell Biol. 1999;11(2):274-286.

121. Moritz M, Agard DA. Gamma-tubulin complexes and microtubule nucleation. Curr Opin Struct Biol. 2001;11(2):174-181.

122. Ryoo S, Lemmon CA, Soucy KG, et al. Oxidized low-density lipoprotein-dependent endothelial arginase II activation contributes to impaired nitric oxide signaling. Circ Res. 2006;99(9):951-960.

123. Sun D, Huang A, Sharma S, Koller A, Kaley G. Endothelial microtubule disruption blocks flow-dependent dilation of arterioles. Am J Physiol Heart Circ Physiol. 2001;280(5):H2087-H2093.

124. Colangelo S, Langille BL, Steiner G, Gotlieb AI. Alterations in endothelial $\mathrm{F}$-actin microfilaments in rabbit aorta in hypercholesterolemia. Arterioscler Thromb Vasc Biol. 1998;18(1):52-56.

125. Cucina A, Sapienza P, Borrelli V, et al. Nicotine reorganizes cytoskeleton of vascular endothelial cell through platelet-derived growth factor BB. J Surg Res. 2000;92(2):233-238.

126. Gabbiani G, Elemer G, Guelpa C, Vallotton MB, Badonnel MC, Hüttner I Morphologic and functional changes of the aortic intima during experimental hypertension. Am J Pathol. 1979;96(2):399-422.

127. Yu PK, Yu DY, Cringle SJ, Su EN. Endothelial F-actin cytoskeleton in the retinal vasculature of normal and diabetic rats. Curr Eye Res. 2005;30(4):279-290.

128. Kadi A, de Isla N, Lacolley P, Stoltz JF, Menu P. Potential relation between cytoskeleton reorganization and e-NOS activity in sheared endothelial cells (Effect of rate and time of exposure). Clin Hemorheol Microcirc. 2007;37(1-2):131-140.

129. Searles CD, Ide L, Davis ME, Cai H, Weber M. Actin cytoskeleton organization and posttranscriptional regulation of endothelial nitric oxide synthase during cell growth. Circ Res. 2004;95(5):488-495.

130. Laufs U, Endres M, Stagliano N, et al. Neuroprotection mediated by changes in the endothelial actin cytoskeleton. J Clin Invest. 2000; 106(1):15-24.

131. Ou H, Shen YH, Utama B, et al. Effect of nuclear actin on endothelial nitric oxide synthase expression. Arterioscler Thromb Vasc Biol. 2005; 25(12):2509-2514.
132. Zhang MX, Zhang C, Shen YH, et al. Effect of 27nt small RNA on endothelial nitric-oxide synthase expression. Mol Biol Cell. 2008;19(9): 3997-4005.

133. SuY, Zharikov SI, Block ER. Microtubule-active agents modify nitric oxide production in pulmonary artery endothelial cells. Am J Physiol Lung Cell Mol Physiol. 2002;282(6):L1183-L1189.

134. Brum Cde A, Duarte ID, Webb RC, Leite R. Disruption of microtubular network attenuates histamine-induced dilation in rat mesenteric vessels. Am J Physiol Cell Physiol. 2005;288(2):C443-C449.

135. Ryoo S, Bhunia A, Chang F, Shoukas A, Berkowitz DE, Romer LH. OxLDL-dependent activation of arginase II is dependent on the LOX-1 receptor and downstream RhoA signaling. Atherosclerosis. 2011; 214(2):279-287.

136. Dharmashankar K, Widlansky ME. Vascular endothelial function and hypertension: insights and directions. Curr Hypertens Rep. 2010; 12(6):448-455.

137. Hashimoto-Komatsu A, Hirase T, Asaka M, Node K. Angiotensin II induces microtubule reorganization mediated by a deacetylase SIRT2 in endothelial cells. Hypertens Res. 2011;34(8):949-956.

138. Xu SQ, Mahadev K, Wu X, et al. Adiponectin protects against angiotensin II or tumor necrosis factor alpha-induced endothelial cell monolayer hyperpermeability: role of cAMP/PKA signaling. Arterioscler Thromb Vasc Biol. 2008;28(5):899-905.

139. Ai L, Rouhanizadeh M, Wu JC, et al. Shear stress influences spatial variations in vascular Mn-SOD expression: implication for LDL nitration. Am J Physiol Cell Physiol. 2008;294(6):C1576-C1585.

140. Ali MH, Mungai PT, Schumacker PT. Stretch-induced phosphorylation of focal adhesion kinase in endothelial cells: role of mitochondrial oxidants. Am J Physiol Lung Cell Mol Physiol. 2006;291(1): L38-L45.

141. Liu Y, Li H, Bubolz AH, Zhang DX, Gutterman DD. Endothelial cytoskeletal elements are critical for flow-mediated dilation in human coronary arterioles. Med Biol Eng Comput. 2008;46(5):469-478.

142. Cunningham KS, Gotlieb AI. The role of shear stress in the pathogenesis of atherosclerosis. Lab Invest. 2005;85(1):9-23.

143. Skidgel RA. Proliferation of regulatory mechanisms for eNOS: an emerging role for the cytoskeleton. Am J Physiol Lung Cell Mol Physiol. 2002;282(6):L1179-L1182.

144. Knudsen HL, Frangos JA. Role of cytoskeleton in shear stress-induced endothelial nitric oxide production. Am J Physiol. 1997;273(1 Pt 2): $\mathrm{H} 347-\mathrm{H} 355$.

145. Su Y, Edwards-Bennett S, Bubb MR, Block ER. Regulation of endothelial nitric oxide synthase by the actin cytoskeleton. Am J Physiol Cell Physiol. 2003;284(6):C1542-C1549.

146. Ali MH, Pearlstein DP, Mathieu CE, Schumacker PT. Mitochondrial requirement for endothelial responses to cyclic strain: implications for mechanotransduction. Am J Physiol Lung Cell Mol Physiol. 2004; 287(3):L486-L496.

147. Mendoza SA, Fang J, Gutterman DD, et al. TRPV4-mediated endothelial $\mathrm{Ca} 2+$ influx and vasodilation in response to shear stress. Am J Physiol Heart Circ Physiol. 2010;298(2):H466-H476.

148. Usatyuk PV, Romer LH, He D, et al. Regulation of hyperoxiainduced NADPH oxidase activation in human lung endothelial cells by the actin cytoskeleton and cortactin. J Biol Chem. 2007;282(32): 23284-23295.
Cell Health and Cytoskeleton

\section{Publish your work in this journal}

Cell Health and Cytoskeleton is an international, peer-reviewed open access journal focusing on all aspects of cell structure and function contributing to normal physiology and cell health and exploring the pathogenesis of cell dysfunction leading to adverse conditions and disease in the organism. The journal welcomes papers covering original research,

\section{Dovepress}

basic science, reviews and evaluations, guidelines, expert opinion and commentary, case reports and extended reports. The manuscript management system is completely online and includes a very quick and fair peerreview system, which is all easy to use. Visit http://www.dovepress.com/ testimonials.php to read real quotes from published authors. 